\title{
The Effects of Municipal Policy on Green Building Designations in the United States
}

\author{
Eugene Choi*
}

\begin{abstract}
This article describes the results of a quantitative examination of the effect of municipal policies on the number of commercial office buildings with a green building designation. Many states and cities have adopted green building requirements and incentives as policy instruments. During this study, an ordinary least square (OLS) regression analysis was conducted using American inner cities as a unit of analysis and coding municipal green building regulations and incentives as four separate dummy variables. The study also included four factors grouped by a factor analysis-supply-side factors, demand-side factors, air quality, and temperature-to control for external effects that can affect the decision to implement green building construction. The results indicate that, at the municipal level, regulatory policy has been a strong tool to promote green office building developments, as expected, but incentive-based policies have not been as effective, with the exception of administrative incentives.
\end{abstract}

Keywords: green buildings, municipal policies, regulations, incentives

\section{INTRODUCTION}

Green buildings have emerged as a major tool to increase sustainability in urban areas. It is believed that greening real estate has improved overall energy consumption (Rajgor 2005; Fellows 2006; Pan, Yin, and Huang 2008), indoor air quality (James and Yang 2005; Matela 2006; Borrelli 2007; Richardson and Lynes 2007; Prasow 2008), occupants' satisfaction and office occupancy rates (Paul and Taylor 2008; Prasow 2008; Fuerst and McAllister 2009), and rental and sales revenues (Miller, Spivey, and Florance 2008; Fuerst and McAllister 2008; Dermisi 2009). Under the assumption

\footnotetext{
* Eugene Choi is an adjunct instructor at the Levin College of Urban Affairs, Cleveland State University and will be a BK researcher at Seoul National University in Korea as of September 2010. His research focuses on urban sustainability, green (re) development and general environmental studies. E-mail: e.choi99@csuohio.edu.
}

Manuscript received March 5, 2010; out for review June 14, 2010; review completed July 5, 2010; accepted July 7, 2010.

The Korean Journal of Policy Studies, Vol. 25, No. 2 (2010), pp. 39-63.

(C) 2010 by the GSPA, Seoul National University 
that these externalities can be generated by being green, city- and state-level decision makers have adopted various green building requirements as policy instruments. In addition, many nonprofit organizations have significantly influenced the green building movement. The grassroots-level push for green building was heard by politicians, and the response has been an increase in public policies to encourage these types of developments. As a result, the green building movement continues to grow rapidly. The U.S. Green Building Council (USGBC), a nonprofit organization dedicated to sustainable building design and construction, developed the Leadership in Energy and Environment Design (LEED) building rating system. The United States experienced a 50 percent cumulative increase in LEED-registered projects and a nearly 70 percent increase in LEED-certified projects between 2000 and 2006.

This study tested the impact of both regulatory and incentive-based green building policies at the city level on the rate of green office building designations, particularly for the private sector. Perhaps there is less need to implement green building policies at the federal and state levels of government; however, fear of increased costs and regulations may foster reluctance among local governments to implement any policy that would discourage building in smaller cities or those with weaker economies that compete to attract businesses.

In this study, "green office building" refers to office buildings registered with the LEED green building rating system or with Energy Star, a similar program developed in 1992 by the U.S. Environmental Protection Agency. LEED considers whether the design, construction, and operation of buildings is in accordance with environmental considerations. It was developed from a checklist of recommended construction practices to include development; it is an ongoing collaborative process between architects, builders, and building owners and operators (Simons, Choi and Simons 2009). Energy Star's focus is on reducing energy consumption in order to lower greenhouse gas emissions. It measures the energy efficiency of buildings, building systems, and equipment used inside homes and other buildings. It has been incorporated into LEED standards for the renovation of existing buildings (Simons, Choi, and Simons 2009).

Other green building rating systems are also used in the United States, such as Green Globe and Green Seal. Green Globe is a set of international standards initially endorsed by 182 heads of state at the United Nations Rio De Janeiro Earth Summit in 1992. Founded in 1989, Green Seal is a nonprofit entity helping set standards for the service industry and individual products (Simons, Choi, and Simons 2009). This study did not include office buildings designated under either of these systems, because the number of office buildings registered under them in each inner city could not be obtained.

This study was based on data obtained from Internet research as of October 
2009. Public policies at the municipal level were divided into two categories: regulatory and incentive-based. Incentive-based policy can be further divided into three subcategories: administrative incentives, financial incentives, and technical support. For the statistical model, therefore, these four public policies-regulatory policy and three incentive-based policies - were coded as separate dummy variables. An ordinary least square (OLS) regression analysis was conducted using central cities in the United States as the unit of analysis. The market penetration of commercial green office buildings in each central city was the dependent variable, while the policy dummy variables served as independent variables. Eight control variables were used to account for the demand- and supply-side factors of green buildings as well as to control for environmental factors. Factor analysis was used to reduce the nine control variables into three factors, because the sample size $(n=103)$ was not large enough to run the regression model with an array of 13 explanatory variables (four policy dummy variables and nine control variables). An additional OLS regression analysis was conducted to test whether a city that has used both regulation policy and incentive-based policy experiences an effect on market penetration that is different from that of a city that has used a regulation policy or an incentive-based policy alone.

\section{LITERATURE REVIEW}

The growing importance of the green building concept has affected not only urban policy makers and planners but also scholars. Reflecting this practical trend, many academic articles have been published since 2000 in major planning or policy journals such as the Journal of Planning Literature, Energy Policy, Journal of Planning Education and Research, and Economic Development Quarterly. Themes of articles dealing with green buildings can be classified into four broad categories: motivations for being green, policy adaptation, benefits of and obstacles to achieving a green designation, and green design. This study considered public policies as motivations of green building construction.

Although American cities have experienced a rapid increase in the number of green buildings, few empirical studies have focused on public policy while analyzing factors that may affect green building development. Several motivators for private sector greening have been discussed in previous studies: supply-side factors such as increased property value and rents (Miller, Spivey, and Florance 2008; Fuerst and McAllister 2008; Dermisi 2009), demand-side factors (Clemens and Douglas 2006; Richardson and Lynes 2007; Paul and Taylor 2008; Simons, Choi, and Simons 2009), environmen- 
tal conditions, and public policy (Simons, Choi, and Simons 2009). Operators, tenants, owners, and building developers tend to value these motivators differently.

\section{Supply-Side Factors}

Real estate deals are strongly affected by supply-side factors. Green office building initiatives may also be affected by supply-side factors in the existing office building market. These include availability of or vacancies in existing office stock, rents or sales prices of existing or planned office buildings, and the current condition of existing office stock (Rosen 1984; Tse and Webb 2003). Higher vacancy and availability rates motivate developers not to invest in green office buildings, because these two proxies indicate either that the office market is down for new construction (and it is hard to find buyers or tenants) or that competition is too tough to warrant the added investment costs for new green office building construction. Current building conditions may influence owners or operators of older office buildings to convert their properties to green buildings, because the cost of rehabilitating a property and simultaneously converting it to a green property can be less than the cost of carrying out the two processes separately.

Previous studies of rents or sales prices of green buildings are important because the existence of a rent or sales price premium for green office buildings indicates that markets can price the benefits of investment in Energy Star and LEED certification (Simons, Choi, and Simons 2009). In other words, developers or building owners can derive more benefits from green investment. Two papers presented at the American Real Estate Society annual meeting in 2008 investigated the difference between buildings designated as green by Energy Star or LEED and conventional buildings (Miller, Spivey, and Florance 2008; Fuerst and McAllister 2008; Dermisi 2009) in terms of rents and building sales prices. Both papers both found market premiums for green building in both categories.

\section{Demand-Side Factors}

Who wants to buy or work in green office buildings? A recent study found that buyers and tenants who think green office buildings are more comfortable than conventional office buildings generate demand (Paul and Taylor 2008). This study compared occupant comfort and satisfaction in a green building and a conventional building. Researchers collected the comfort and satisfaction perceptions of the occupants of a green university building and two conventional university buildings using a questionnaire that asked occupants to rate their workplace environment in terms of 
aesthetics, serenity, lighting, acoustics, ventilation, temperature, humidity, and overall satisfaction.

Buyers and tenants who consider public perception or who think that going green is the right thing to do also generate demand for green office buildings (Simons, Choi, and Simons, 2009). Under this assumption, it is logical that if a city has more educated people, it is likely to possess more green office buildings.

Often a lack of internal leadership among stakeholders is very important for green office building development, because this value is not related to tangible benefits. Richardson and Lynes (2007) pointed out the importance of internal leadership and communication between participants in green office building development. They explored the barriers to and motivations for the construction of green buildings at the University of Waterloo. The authors conducted 13 in-depth interviews with key university individuals and found that a lack of internal leadership among stakeholders with decision-making power, a lack of quantifiable sustainability targets, an operational structure that does not reward building designs with lower energy costs, and a lack of communication between professional designers, facilities management staff, and faculty were all barriers to constructing green buildings at the university.

\section{Environmental Conditions}

Simons, Choi, and Simons (2009) pointed out that climate can motivate green building initiatives: cities that experience many days of sunshine are able to utilize solar panels; limited access to water and higher water costs motivate water conservation; and warmer climates use more electricity for air conditioning, motivating building users to provide shade and green roofs.

Green building developments can be motivated by the need for environmental protection. They have been used in the context of local commitment to the U.S. Mayors' Climate Protection Agreement and other programs that address climate change (Retzlaff 2009). Although some environmental benefits are not easily quantified, it is believed that green buildings generate less pollution and landfill waste. According to the U.S. Department of Energy (2008), buildings in the United States contribute 38.1 percent of the nation's total carbon dioxide emissions, 20.6 percent from the residential sector and 17.5 percent from the commercial sector. For the public, green buildings can be a good tool to reduce air and water pollution by using eco-friendly building materials, recycling or reusing old materials, and using eco-friendly energy sources such as fuel cells. 


\section{Public Policy}

Simons, Choi, and Simons (2009) qualitatively investigated the impact of public policies on the market penetration of green commercial office buildings. The research had limited generalized findings because the results were drawn from case studies. They researched policies at both the state and city level through various methods, such as Internet research and interviews with pubic officials. They found that many local municipalities in California have adopted green building codes that were mandated for public funding of projects. They also noted that some financial incentives had been established but were no longer funded in California. Moreover, the standards were voluntary for private developers. According to their research, Chicago not only encourages LEED design for all new buildings, but also works with existing building owners and operators to incorporate Energy Star efficiencies in rehabilitation projects. Simons, Choi, and Simons (2009) concluded that the most common form of public policy is to require LEED for all public buildings. Several states call this leading by example and specify that government buildings and/or school buildings be LEED certified, Energy Star rated, or both. They suggested that starting with publicly financed new buildings such as schools is the best way to lead by example and gain knowledge about the green building process.

\section{Municipal Green Building Policies}

Based in part on information derived from a review of the academic literature, Web sites for central cities that possess more than one green office building were reviewed. The intent was to ascertain whether or not city governments apply green building policies. The search phrases used were "green building requirement" and "green building incentives." Appendix 1 lists all central cities that have implemented municipal green building policies.

Green policies can be adopted through either executive orders or legislation. Executive orders are a quicker method for implementing policy. Legislation often gets bogged down by politics, as competing political agendas often stall green legislation (Simons, Choi, and Simons 2009). The general concept for implementing green building techniques through regulatory policies is straightforward: requiring that some or all newly constructed or renovated buildings in certain zoning areas must meet LEED or equivalent requirements (Retzlaff 2009). Some municipalities have established such mandates (Yudelson Associates 2007), while some state governments have required their public buildings to utilize green building techniques (May and Koski 2007). Regulation is viewed as the most powerful policy tool for promoting specific development 
activities, because a city or a state can conduct disciplinary action for noncompliance.

Central cities also utilize three types of incentive-based policies to encourage green building - administrative incentives, financial incentives, and technical supports (Retzlaff 2009; Simons, Choi, and Simons 2009). With administrative incentives, green building projects pass through the plan review and approval process faster so that developers can save time and money. Financial incentives include tax credits, funds, and rebates for green building developers. With technical support, a municipality provides every effort for the developers who want their properties to be green certified; this support is very useful, since green building requirements are often new and unfamiliar to private sector initiators.

\section{Green Building Profiles in the United States}

The U.S. Environmental Protection Agency defines green building as the practice of creating structures and using processes that are environmentally responsible and resource-efficient throughout a building's life cycle, from siting to design, construction, operation, maintenance, renovation and demolition. This practice expands and complements the classical building design concerns of economy, utility, durability, and comfort. Green buildings are also regarded as sustainable high-performance buildings that are designed to reduce waste sent to landfills, conserve energy and water, provide a safe and healthy environment for occupants, reduce greenhouse gas emissions, and reduce operating costs for the building owner, savings that can then be passed on to tenants through lower rents and utility costs. Green buildings may incorporate sustainable materials in their construction (for example, materials that are reused, recycled, or made from renewable resources), create healthy indoor environments with minimal pollutants (for example, reduced product emissions), and feature landscaping that reduces water usage (for example, by using native plants that need less water to survive).

Figure 1 depicts the number of green office buildings in the United States with Energy Star designations since 2001. In the fourth quarter of 2001, 2,215 office buildings were certified by Energy Star, and in the second quarter of 2009, 2,468 office buildings were certified by Energy Star, showing an increase of over 10 percent during this period. According to an online database maintained by CoStar, 388 green office buildings were certified by LEED in the fourth quarter of 2001, and 729 in the second quarter of 2009, an increase of about 47 percent (see figure 2). 
Figure 1. Office Buildings with Energy Star Certification

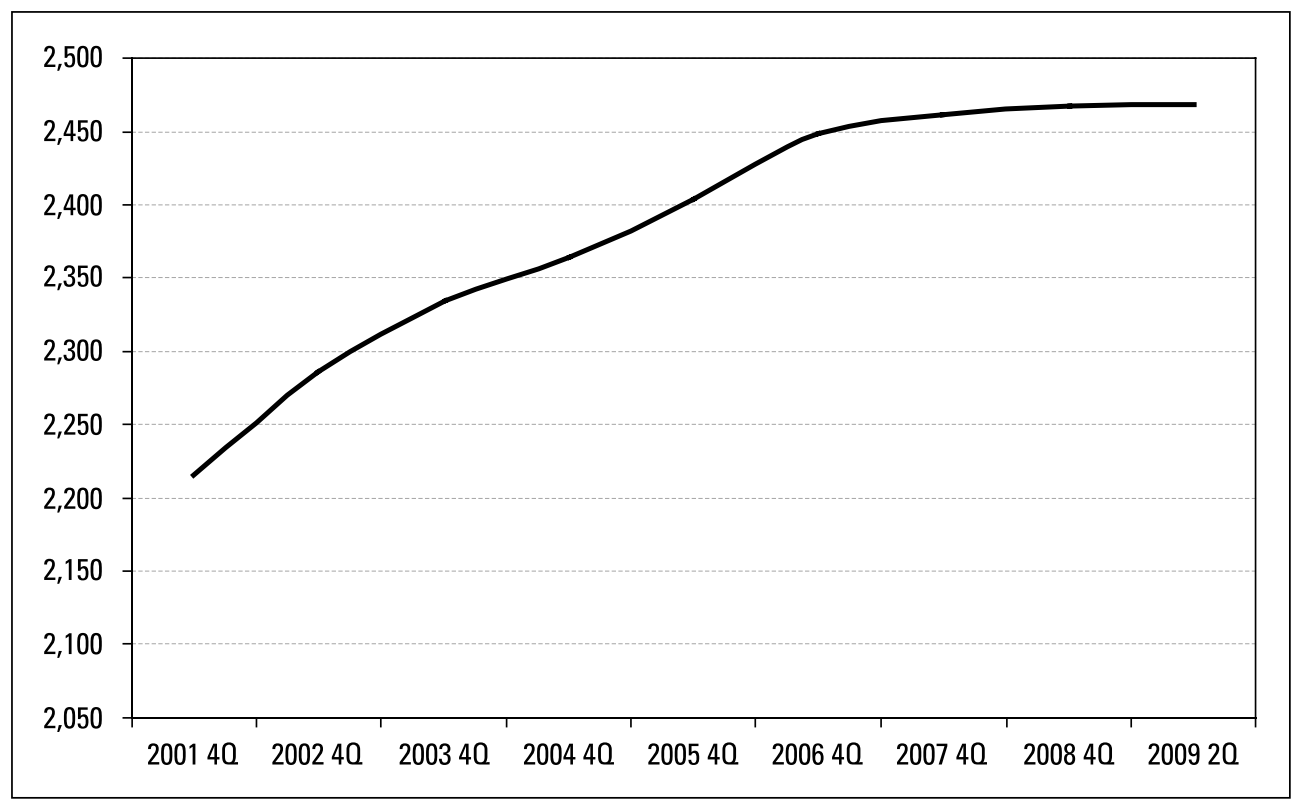

Source: www.costar.com.

Figure 2. Office Buildings with LEED Certification

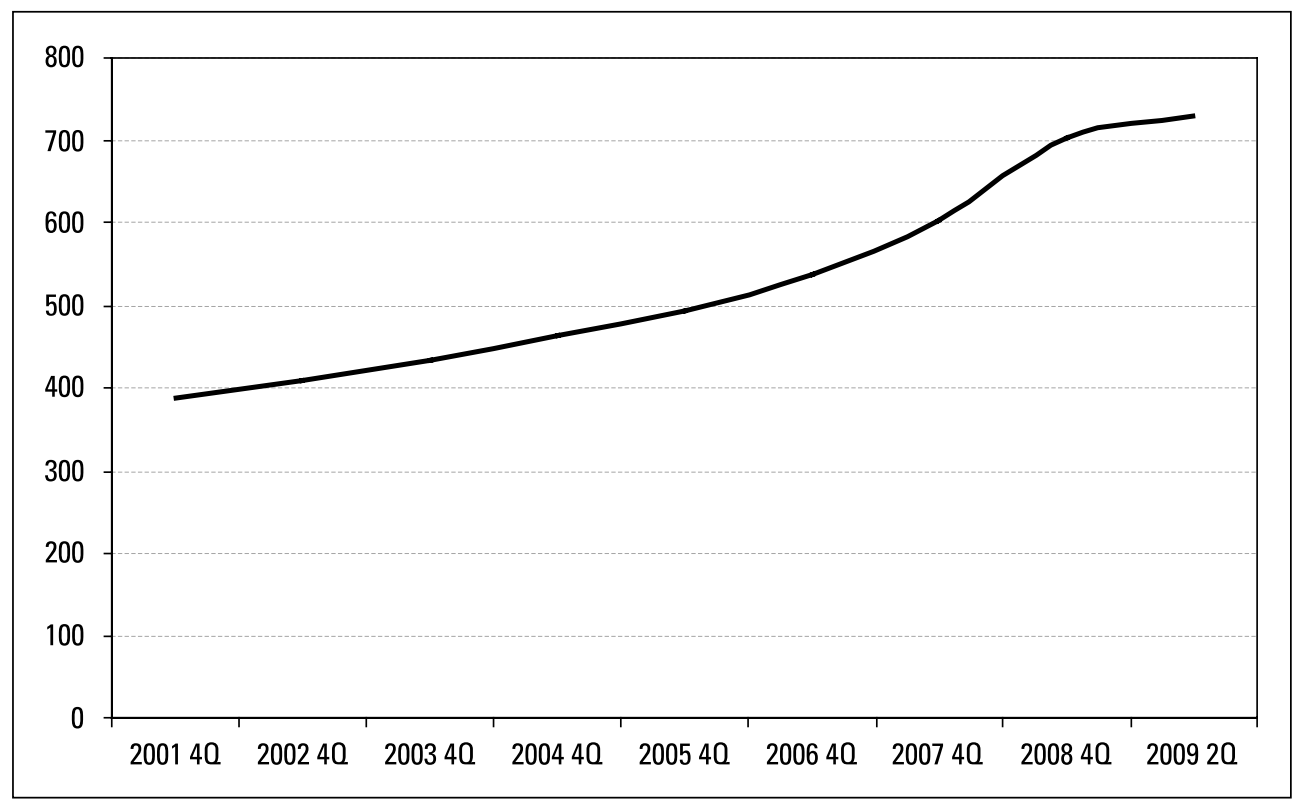

Source: www.costar.com.

The Korean Journal of Policy Studies 
Figure 3 depicts new construction of green office buildings certified by Energy Star or LEED since 2001 in the United States. It shows that approximately 200 green office buildings were constructed around 2000. It appears that since USGBC developed the LEED standards in 1998, many efforts in the private sector have been made to meet the standards. However, new construction of green office buildings has experienced a rapid decrease since 2008; the continuing economic crisis may explain this reversal.

Figure 3. New Construction of Green Office Buildings

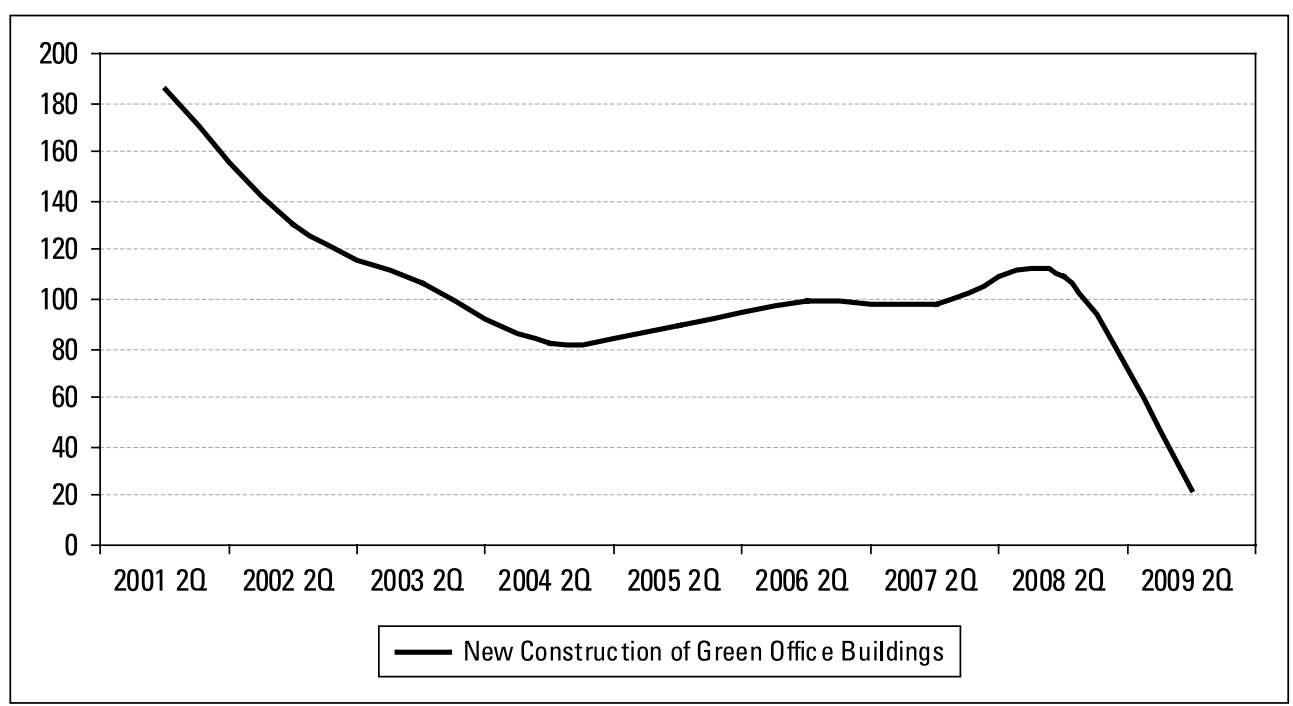

Source: ww w.costar.com.

Table 1 lists the 20 states with the most green office buildings. As of March 26, 2009, there were 2,801 green office buildings in the United States listed in the CoStar database as having rental vacancies and green status. The top 10 states possess approximately 70 percent of all green office buildings. The average number of green office buildings per million people was approximately 8.26; only 13 states exceeded this average. 
Table 1. Top 20 States with Green Office Buildings

\begin{tabular}{|c|c|c|c|}
\hline \multicolumn{2}{|c|}{ Number of buildings } & \multicolumn{2}{|c|}{ Number of buildings per million state residents } \\
\hline State & Offices & State & Offices per million people \\
\hline California & 691 & District of Columbia & 135.17 \\
\hline Texas & 285 & Colorado & 31.38 \\
\hline Colorado & 155 & California & 18.80 \\
\hline Illinois & 113 & Oregon & 16.89 \\
\hline Massachusetts & 96 & Minnesota & 15.52 \\
\hline Washington & 88 & Massachusetts & 14.77 \\
\hline Florida & 88 & Hawaii & 14.75 \\
\hline Minnesota & 81 & Washington & 13.44 \\
\hline New York & 80 & Texas & 11.72 \\
\hline District of Columbia & 80 & Virginia & 10.04 \\
\hline Virginia & 78 & Arizona & 8.77 \\
\hline Pennsylvania & 73 & Illinois & 8.76 \\
\hline Georgia & 73 & Connecticut & 8.28 \\
\hline Oregon & 64 & Maryland & 7.63 \\
\hline Michigan & 63 & Georgia & 7.54 \\
\hline Arizona & 57 & Kansas & 6.78 \\
\hline North Carolina & 51 & Michigan & 6.30 \\
\hline New J ersey & 50 & Pennsylvania & 5.86 \\
\hline Ohio & 48 & New J ersey & 5.76 \\
\hline Maryland & 43 & Delaware & 5.73 \\
\hline
\end{tabular}

Source: Adapted from Simons, Choi, and Simons 2009. Data from: w w w.costar.com.

$\mathrm{N}=2,801$.

Figure 4 shows the distribution of green office buildings throughout the United States, expressed as the number of buildings per million. Western states such as Texas, Colorado, Washington, Oregon, and California have more than 10 office green buildings per million people. No green office buildings were found in as the northern states of Montana, North Dakota, South Dakota, and Wyoming. This result seems to be due to cold weather in these states. In addition, no green office buildings were found in Vermont and New Hampshire. This result seems to be due to the small market for commercial office space in these states. 
Figure 4. Distribution of Green Office Buildings

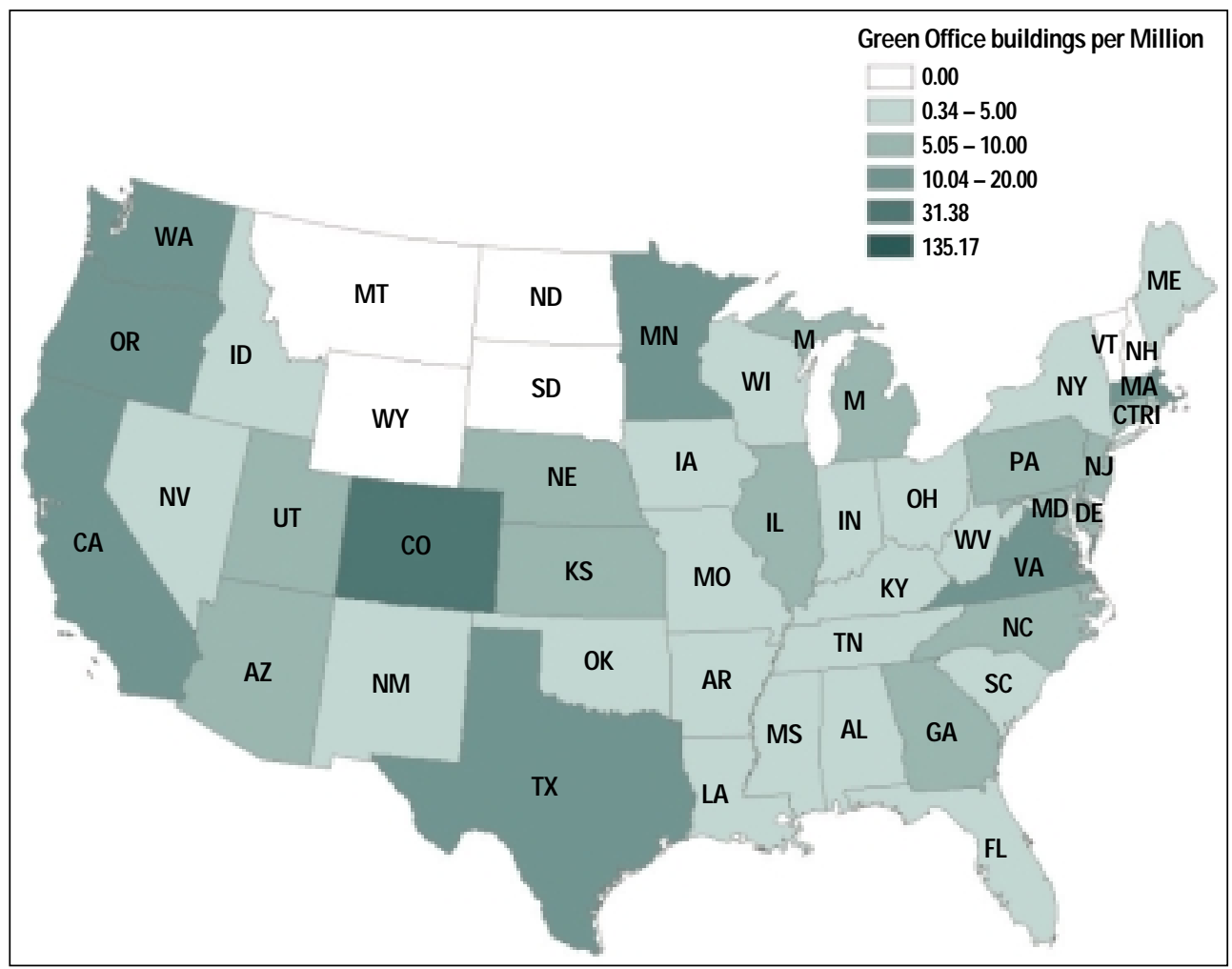

Source: based on data from www.costar.com.

Table 1 and Figure 4 show that the green building movement is not a uniform nationwide trend. It has been concentrated in several states, especially in the western states (Simons, Choi, and Simons 2009).

Table 2 shows the market penetration rate for green office buildings in the top 10 central cities in the United States. This rate was calculated by dividing the number of green office buildings by the total number of office buildings in the city. 
Table 2. M arket Penetration for Green Office Buildings

\begin{tabular}{lccc}
\hline City & Green office buildings & Total office buildings & Market penetration (\%) \\
\hline San Francisco, CA & 102 & 1,638 & 6.23 \\
\hline Houston, TX & 129 & 2,189 & 5.89 \\
\hline Washington, DC & 81 & 1,750 & 4.63 \\
\hline Denver, CO & 56 & 1,296 & 4.32 \\
\hline Duluth, M N & 5 & 118 & 4.24 \\
\hline M inneapolis, M N & 23 & 593 & 3.88 \\
\hline Seattle, WA & 47 & 1,266 & 3.71 \\
\hline Honolulu, HI & 11 & 300 & 3.67 \\
\hline Burlington, NC & 4 & 112 & 3.57 \\
\hline Chicago, IL & 62 & 1,790 & 3.46 \\
\hline Sor CoStr, & & &
\end{tabular}

Source: CoStar, Inc. (www.costar.com)

In San Francisco, both incentive-based and regulatory policies are in place and seem to be working. According to San Francisco's Department of the Environment, projects that commit to LEED Gold certification are eligible for priority permit processing through coordination with the Planning Department, Department of Building Inspection, and Department of Public Works. Rebates for installation of photovoltaic systems and water efficiency and energy efficiency measures are also available from the San Francisco Public Utilities Commission. Coupled with the California Solar Initiative state rebates and federal tax credits, incentives can pay half the cost of a solar power system installed in an office building in San Francisco. In terms of regulations, the city enacted private sector green building requirements that became effective November 2008. Chapter 13C of the San Francisco Building Code will require new buildings constructed in the city to meet green building standards, which were developed by the Green Building Task Force. In addition, all municipal projects, both new construction and major renovations over 5,000 square feet, are required to achieve LEED Silver certification.

\section{METHODOLOGY}

\section{Study Area}

This study used America's central cities as a unit of analysis. Central cities are defined as core urban areas; they often have higher poverty and crime rates and lower 
median household incomes than the surrounding metropolitan statistical area. It is believed, moreover, that central cities have relatively poor environmental conditions, such as lower air and watershed quality, than suburban areas (Warner 2001; Harner, Warner, Pierce, and Huber 2002; Rast 2006; Chambers 2007). On the other hand, many sources of employment, including commercial offices, are concentrated in the central cities. This study assumed that green building policies are more common in central city areas than suburban areas. The principal cities of each metropolitan statistical area were considered the central cities, but not all central cities in the United States have green office buildings. Central cities without green office buildings were not included in the sample, leaving 103 central cities in the study. California has the most central cities (14) with green buildings, followed by Florida, North Carolina, and Texas, each with six central cities possessing green office buildings.

\section{Data}

The dependent variable for this study was the market penetration rate of green office buildings in each central city. The market penetration of green office buildings is measured as the ratio of green office buildings to total office buildings. This data was obtained from CoStar's database (www.costar.com).

Each category of green building policy-regulatory policy, administrative incentives, financial incentives, and technical support—was coded as a separate dummy variable. The policy categories were based on the following criteria:

- Regulatory policy_requirements for new and rehabilitated commercial buildings to meet LEED standards or the equivalent

- Administrative incentives_-priority in the building permit process, expedited development plan review, and marketing materials

- Financial incentives-various tax incentives including credits and refunds; grants and rebates for green building development

- Technical support-technical support for construction or rehabilitation methods, building preparation, site evaluation, material selection, and training

The study used average office rent (expressed in dollars per square foot per year), average office age, and average rentable building area to control for the effects of supply-side factors on green building development. The percentage of white population, the percentage of population with a graduate or professional degree, and the median household income were used to control for the effects of demand-side factors on green building development. To account for the environmental motivations of green building initiatives, controls for the density of carbon and ozone were integrated into the analy- 
sis. Since the number of sunny days may affect green building development (Simons, Choi, and Simons 2009), the study included the average temperature in July for the last 30 years as a control variable.

Retzlaff (2009) divided municipal policies affecting the use of the LEED building assessment system into three categories: policies affecting buildings that are funded or owned by municipalities, policies affecting private development, and incentives. According to Retzlaff, the inclusion of LEED in municipal policies is a new trend; prior to 2000, only two cities-Austin, Texas, and Scottsdale, Arizona—had adopted green building policies. Regarding the private sector, which is the focus of this paper, she found that no jurisdiction had enacted a policy that required all buildings to meet LEED standards; however, some places require multiple types of buildings, all buildings in certain zoning districts, or all buildings over a certain size to use LEED.

The NAIOP Research Foundation retained Yudelson Associates in 2007 to investigate local government incentive programs for green building construction. Yudelson Associates' report was based on case studies and survey research. They found that "incentive payment from a utility energy-efficiency program" and "direct monetary payment from a city or county (grant, rebate or reimbursement)" were two most popular incentives for green building construction by the private sector. They also listed current government programs at the local level by city or state. They found that local governments have increasingly instituted policies, programs, and incentives in the effort to encourage sustainable buildings (Yudelson Associates 2007).

USGBC (2009) published a report that discussed green building policies at the local level. According to the report, the first step for local governments is to set strong green building standards for new and retrofitted public buildings, including schools, public safety faculties, libraries, and administrative offices. The second step is to encourage private development using various financial incentives for commercial and residential buildings. The report stated that the ultimate goal of green building policies is to green cities through smart financing and building codes. To lower real or perceived cost barriers to green building and to achieve even greater market penetration, innovative local governments are developing creative financing models to help residents and other building owners invest in green buildings. In addition, leading local governments are implementing and enforcing building codes to support sustainability goals (USGBC 2009).

The provisions of state green requirements include incentives for constructing green buildings as well as mandates for adherence to LEED provisions for new facilities and for renovated buildings that meet specified size or value requirements (May and Koski 2007). As Simons, Choi, and Simons (2009) and May and Koski (2007) pointed out, most state policies promote the utilization of green building techniques in 
state buildings, schools, and other public facilities, while municipal policies more often focus on promoting green construction in the private sector. In other words, the state requirements do not affect single-family homes or commercial structures. Therefore, this study assumed that municipal policies may have a greater effect on the market penetration of green buildings than state policies, because municipal policies deal with commercial developers' investments. In addition, municipalities may be the best places for green policies because they have the organizational structures to adopt and enforce development regulations, they can respond best to local government conditions and issues, and public sustainability activism is more meaningful and effective at the local level (Theaker and Cole 2001). Working from this position, this study was primarily concerned with whether the market penetration of green office buildings has been affected by municipal policies, including both regulatory policies and incentivebased policies, while controlling for other external factors that can affect green building initiatives.

Table 4. Descriptions of Variables

\begin{tabular}{lll}
\hline Variable & \multicolumn{1}{c}{ Description } & \multicolumn{1}{c}{ Source } \\
\hline MP & $\begin{array}{l}\text { Market penetration (number of green office buildings divided by } \\
\text { total number of office buildings) }\end{array}$ & w ww.costar.com \\
\hline LNOFFICERENT & Natural logarithm of average office rent per year per square foot & w ww.costar.com \\
\hline LNOFFICEAGE & Natural logarithm of average office age & w ww.costar.com \\
\hline LNRBA & Natural logarithm of the average rentable building area & w ww.costar.com \\
\hline WHITE & Percentage of the population that is white & Census 2000 \\
\hline GRADUDEGREE & Percentage of the population with a graduate or professional degree & Census 2000 \\
\hline LNINCOME & Natural logarithm of median household income & Census 2000 \\
\hline LNCARBON & Natural logarithm of carbon density & www.airnow .gov \\
\hline LNOZONE & Natural logarithm of ozone density & w ww .airnow.gov \\
\hline TEM PERATURE & Average temperature in J uly in the last 30 years & w ww.city-data.com \\
\hline REGULATION & Presence of a regulation policy (dummy variable) & Internet research \\
\hline ADINCENT & Presence of an administrative incentive (dummy variable) & Internet research \\
\hline FINAINCENT & Presence of a financial incentive (dummy variable) & Internet research \\
\hline TECHINCENT & Presence of a technical support incentive (dummy variable) & Internet research \\
\hline
\end{tabular}

Table 5 presents basic statistics on the factors used as dependent variables and used for factor analysis in this study. 
Table 5. Descriptive Statistics

\begin{tabular}{lrrrr}
\hline Variable & Minimum & Maximum & Mean & $\begin{array}{r}\text { Standard } \\
\text { deviation }\end{array}$ \\
\hline M arket penetration & $0.04 \%$ & $6.23 \%$ & $1.38 \%$ & $1.41 \%$ \\
\hline Office rent & $\$ 10.19$ & $\$ 52.82$ & $\$ 20.33$ & $\$ 7.01$ \\
\hline Office age & 19.50 & 89.40 & 43.66 & 16.02 \\
\hline Rentable building area (SF) & $809,261.00$ & $494,050,780.00$ & $36,360,186.74$ & $59,707,504.82$ \\
\hline Percentage of population that is white & $7.00 \%$ & $92.00 \%$ & $52.91 \%$ & $21.40 \%$ \\
\hline Percentage of population with a & $2.00 \%$ & $49.00 \%$ & $10.63 \%$ & $6.61 \%$ \\
graduate degree & $\$ 23,234$ & $\$ 99,102$ & $\$ 37,496$ & $\$ 9,852$ \\
\hline M edian household income & 1.00 & 5.10 & 2.32 & 0.74 \\
\hline Carbon density & 0.04 & 0.10 & 0.08 & 0.01 \\
\hline Ozone density & 62.80 & 92.80 & 76.78 & 5.94 \\
\hline Temperature & & & &
\end{tabular}

Table 6 summarizes the types of green building policies in place in 103 central cities.

Table 6. Frequency of Green Building Policies

\begin{tabular}{lcc}
\hline Policy & Frequency & Percentage \\
\hline Regulatory policy & 30 & $29.13 \%$ \\
\hline Administrative incentive & 11 & $10.68 \%$ \\
\hline Financial incentive & 9 & $8.74 \%$ \\
\hline Technical support & 6 & $5.83 \%$ \\
\hline
\end{tabular}

\section{Factor Analysis to Reduce Control Variables}

The objective of conducting a factor analysis is data reduction and clarification of data structure. Factor analysis can be used to achieve data reduction by identifying representative variables from a much larger set of variables for use in subsequent multivariate analyses or by creating an entirely new set of variables, much smaller in number, to partially or completely replace the original set of variables. This study had too many variables to run a multiple regression with the sample size of 103 central cities. Therefore, a new set of variables generated by factor analysis was developed for the regression models. The second objective of factor analysis, structuring data, was used to arrange data into several dimensions. 


\section{Model 1}

Using scores obtained from a factor analysis, the following conceptual level regression model was run to investigate the effects of municipal green building policies on the market penetration of green office buildings in the United States:

$$
M P=f(F, R, A, M, T)
$$

where MP = market penetration of green office buildings, $\mathrm{F}=$ vector of factors generated by factor analysis, $\mathrm{R}=$ regulatory policy dummy variable, $\mathrm{A}=$ administrative incentive dummy variable, $\mathrm{F}=$ financial (monetary) incentive dummy variable, and $\mathrm{T}=$ technical support dummy variable.

This conceptual model was used to investigate which type of policy has been the most effective tool for green building development. It portrays the market penetration of green office buildings as a function of F, R, A, M, and T. Based on previous literature, it was expected that regulatory policy would be the most powerful way to promote green building development (Simons, Choi, and Simons 2009). Therefore, model 1 focused on measuring the effects of incentive-based policies, if any, on green building development.

\section{Model 2}

Another regression was used to investigate whether or not incentive-based policies paired with regulatory policy can increase the effects of the regulatory policy on green building development. In other words, Model 2 tests the role of incentive-based policy as a catalyst to green building development if regulatory policy is already in place:

$$
\mathrm{MP}=\mathrm{f}(\mathrm{F}, \mathrm{RO}, \mathrm{IO}, \mathrm{BTH})
$$

where $\mathrm{RO}=$ a dummy variable indicating that a regulation policy has been used, $\mathrm{IO}=\mathrm{a}$ dummy variable indicating that an incentive policy has been used, and $\mathrm{BTH}=\mathrm{a}$ dummy variable indicating that both policies have been used. 


\section{EMPIRICAL RESULTS}

\section{Results of Factor Analysis}

The supply-side variables-LNOFFICERENT, LNOFFICEAGE, and LNRBAwere grouped as one factor and renamed the supply factor, while the demand-side variables-WHITE, GRADUDEGREE, and LNINCOME - were grouped as one factor and renamed the demand factor. The environmental variables LNCARBON and LNOZONE were grouped as the air quality factor. Another environmental factor, temperature, remained as a singular factor due to the results of previous literature that strongly supported the temperature effect on green building development (Simons, Choi, and Simons 2009). Factor scores were used as explanatory variables for the regression models. Table 7 shows the results of the factor analysis.

Table 7. Results of Factor Analysis

\begin{tabular}{|c|c|c|c|c|c|}
\hline \multirow{2}{*}{ Variable } & \multirow{2}{*}{ Factor name } & \multicolumn{4}{|c|}{ Component } \\
\hline & & 1 & 2 & 3 & 4 \\
\hline LNOFFICERENT & Supply factor & .793 & .410 & -.134 & -.040 \\
\hline LNOFFICEAGE & Supply factor & .453 & -.301 & .042 & -.705 \\
\hline LNRBA & Supply factor & .802 & .123 & .228 & .013 \\
\hline WHITE & Demand factor & -.676 & .529 & .152 & -.041 \\
\hline GRADUDEGREE & Demand factor & .083 & .816 & -.021 & -.006 \\
\hline LNINCOME & Demand factor & .128 & .847 & -.126 & .056 \\
\hline LNCARBON & Air quality factor & -.029 & .040 & .827 & -.157 \\
\hline LNOZONE & Air quality factor & .125 & -.370 & .561 & .286 \\
\hline TEM PERATURE & Temperature factor & .161 & -.113 & -.022 & .899 \\
\hline
\end{tabular}

Note: The extraction method was principal component analysis. The rotation method was varimax with Kaiser normalization.

\section{Results of Regression Analysis}

Table 8 presents the regression results using Model 1 to compare the effects of each policy on the market penetration of green office buildings. Variables of Model 1 explain approximately 49 percent of variation (adjusted R-squared $=0.485$ ). The supply factor was statistically significant with a positive relationship between the supplyside factors and green office building development. This result indicates that existing or newly constructed green office buildings are more competitive in a tough market. The air quality factor was statistically significant with a negative sign, indicating that 
if a central city has less air pollution, it is likely to have more green office buildings. This result means that green office building industries are to respond suitability efforts of central city governments. Temperature was statistically significant with a positive sign, meaning higher temperatures were significantly related to green office building development. This result quantitatively confirms Simons, Choi, and Simons's (2009) hypothesis.

Among green building policies, REGULATION and ADINCENT were statistically significant with positive signs, meaning that a city with a green building regulation is likely to have more green office buildings, as is a city that offers administrative incentives; the expected increase of green office buildings is up to 1.0 percent for regulations and 0.6 percent for administrative incentives.

Table 8. Regression Results for M odel 1

\begin{tabular}{|c|c|c|c|c|c|c|}
\hline Variables & B & Std. Error & Beta & $t$ & Tolerance & VIF \\
\hline (Constant) & .009 & .001 & & $6.674 * * *$ & & \\
\hline Supply factor & .003 & .001 & .236 & $2.707 * * *$ & .756 & 1.323 \\
\hline Demand factor & .000 & .001 & .019 & .831 & .875 & 1.143 \\
\hline Air quality factor & -.004 & .001 & -.302 & $-3.855^{* * *}$ & .939 & 1.065 \\
\hline Temperature factor & .003 & .001 & .114 & $2.969 * * *$ & .953 & 1.049 \\
\hline REGULATION & .010 & .003 & .343 & $3.870 * * *$ & .731 & 1.368 \\
\hline ADINCENT & .006 & .005 & .120 & $1.807^{*}$ & .683 & 1.464 \\
\hline FINAINCENT & .002 & .005 & .045 & .458 & .592 & 1.690 \\
\hline TECHINCENT & .009 & .006 & .124 & 1.364 & .696 & 1.436 \\
\hline Adjuste & uared & & & & & \\
\hline
\end{tabular}

Table 9 shows the regression results for Model 2, which tested whether a city that has a regulatory policy and an incentive-based policy is likely to have more green office buildings than a city that has only one or the other. Variables of Model 2 explain approximately 47 percent of the variation (adjusted R-squared $=0.470$ ).

REGULATIONONLY was statistically significant with a positive sign, indicating that a city with a regulatory policy is likely to have more green office buildings than a city without such a policy. In Model 2, the regulatory policy effect reaches up to 1.0 percent. BOTH was statistically significant with a positive sign, meaning that if a city has a regulatory policy with an incentive-based policy, the city is likely to have more green office buildings. The effect of having both policies reaches up to 2.0 percentdouble the effect of having a regulatory policy only. 
In Model 2, regression results for the supply factor, air quality factor, and temperature factor support the results of Model 1 in terms of the direction of the signs and their statistical significance.

Table 9. Regression Results for M odel 2

\begin{tabular}{|c|c|c|c|c|c|c|}
\hline Variables & B & Std. Error & Beta & $t$ & Tolerance & VIF \\
\hline (Constant) & .010 & .001 & & $6.880 * * *$ & & \\
\hline Supply factor & .004 & .001 & .255 & $3.008 * * *$ & .793 & 1.261 \\
\hline Demand factor & .000 & .001 & .032 & .999 & .892 & 1.121 \\
\hline Air quality factor & -.004 & .001 & -.293 & $-3.718 * * *$ & .916 & 1.092 \\
\hline Temperature factor & .002 & .001 & .121 & $1.792 *$ & .989 & 1.011 \\
\hline REGULATIONONLY & .010 & .003 & .291 & $3.512 * * *$ & .830 & 1.205 \\
\hline INCENTIVEONLY & .004 & .005 & .064 & .811 & .915 & 1.093 \\
\hline ВОТН & .020 & .004 & .389 & $4.378 * * *$ & .721 & 1.387 \\
\hline Adjuste & quared & & & & & \\
\hline
\end{tabular}

\section{CONCLUSION AND POLICY IMPLICATIONS}

Only recently have local governments started to look at their regional needs, strengths, and weaknesses to help develop individualized standards for implementing green building policies (Simons, Choi, and Simons 2009). Numerous public policies have been implemented in the last ten years to promote green building in the private sector. Focusing on municipal policies, this study divided policies into two main categories: regulatory and incentive-based. It also divided incentive-based policy into three subcategories: administrative incentives, financial incentives, and technical support. Under regulatory policies, newly constructed or rehabilitated buildings must meet LEED or equivalent requirements. Under administrative incentives, green building projects pass through the plan review and approval process more quickly so that developers can save time and money. Financial incentives include various tax credits, funds, and rebates for green building developers. Technical supports occur when a municipality provides every effort for the developers to get their properties green certified.

Using American central cities as the unit of analysis, this study conducted OLS regression analyses. In the regression model, municipal regulatory policies, administrative incentives, financial incentives, and technical support were coded as four dis- 
tinct dummy variables. The model controlled for the effects of four factors generated by a factor analysis of the independent variables: supply-side factor, demand-side factor, air quality factor, and temperature factor.

Holding other factors constant in Model 1, this study confirmed that municipal regulation and administrative incentives have both been strong tools to promote green office building development.

The strong effects of municipal regulatory policies on green building development have been pointed out previously (Simons, Choi, and Simons 2009). Many central cities with higher market penetration rates of green buildings have regulatory policies, including the top three: San Francisco, Houston, and Washington, D.C.

Municipal administrative incentives have a significant impact on green building development. Green building projects pass through the building permit process faster and are approved more quickly in the plan review phase (Yudelson Associates 2007), which can save developers time and money. This result suggests that developers consider permit and approval processes to be barriers to building development. Choi (2009) pointed out that difficulties involved with identifying appropriate architects, construction firms, construction materials, legal counsel, and other necessities can lengthen a project schedule. Delays often lead to greater risks and higher costs, which developers would rather avoid. In this context, faster building approvals and permitting processes for green building projects lower the risks for private-sector developers and thus promote greener construction.

In contrast, financial incentives have not worked well as a tool for promoting green office building developments. Yudelson Associates (2007) listed municipal financial incentive programs for the private sector: tax credits, refunds and abatements, bond funds, loans, and various fees. Although many central cities have such financial incentive programs in place, they have not been effective in promoting private sector green building developments. This may indicate that financial incentives have been in name only or that they have not been sufficient to offset the construction or rehabilitation costs involved in greening properties. Simons, Choi, and Simons (2009) found that in many cases, particularly in California, existing financial incentives were rarely disbursed to developers. This does not eliminate the possibility that the monetary incentives provided by central cities cannot offset greening costs.

Holding other factors constant in Model 2, this study found that a city that uses a regulatory policy together with an incentive-based policy can significantly stimulate green building development. This result seems reasonable; a city with more motivation (environmental or social) for greening its real properties will use every available policy instrument to achieve its objectives, including a combination of regulatory and incentive-based policies. 


\section{REFERENCES}

Borrelli, F. E. 2007. Vinyl meeting today's and tomorrow's indoor air quality requirements. Journal of Vinyl and Additive Technology 13(3):138-42.

Chambers, S. 2007. Minority empowerment and environmental justice. Urban Affairs Review 43(1):28-54.

Choi, C. 2009. Removing market barriers to green development: Principles and action projects to promote widespread adoption of green development practices. Journal of Sustainable Real Estate 1(1):107-38.

Clemens, B., and T. J. Douglas. 2006. Does coercion drive firms to adopt "voluntary" green initiatives? Relationships among coercion, superior firm resources, and voluntary green initiatives. Journal of Business Research 59(4):483-91.

Dermini, S. V. 2009. Effect of LEED rating and levels on office property assessed and market value. Journal of Sustainable Real Estate 1(1):23-47.

Fellows, R. 2006. Sustainability: a matter of energy? Property Management 24(2): 116-31.

Fuerst, F., and P. McAllister. 2008. An investigation of the effect of eco-labeling on office occupancy rates. Journal of Sustainable Real Estate 1(1):49-64.

Harner, J., K. Warner, J. Pierce, and T. Huber. 2002. Urban environmental justice indices. The Professional Geographer 54(3):318-31.

James J. P., and X. Yang. 2005. Emissions of volatile organic compounds from several green and non-green building materials: A comparison. Indoor and Built Environment 14(1):69-74.

Matela, D. 2006. Air filtration: Green and clean-how to improve indoor air quality. Filtration and Separation 43(9):24-27.

May, P. J., and C. Koski. 2007. State environmental policies: Analyzing green building mandates. Review of Policy Research 24(1):49-65.

Miller, N., J. Spivey, and A. Florance. 2008. Does green pay off? Paper presented at the American Real Estate Society Meeting.

Pan, Y., R. Yin, and Z. Huang. 2008. Energy modeling of two office buildings with data center for green building design. Energy and Buildings 40(7):1145-52.

Paul, W. L., and P. A. Taylor. 2003. A comparison of occupant comfort and satisfaction between a green building and a conventional building. Building and Environment 43(11):1858-70.

Prasow, S. 2008. Acoustics in green buildings: Refining the concept of environmentally quality while improving occupant health and productivity synergistically. Journal of the Acoustical Society of America 123(5):3095.

Rajgor, G. 2005. Energy efficiency business booming. Refocus 6(3):68-69. 
Retzlaff, R. C. 2009. The use of LEED in planning and development regulation: An exploratory analysis. Journal of Planning Education and Research.

Richardson, G. R. A., and J. K. Lynes. 2007. Institutional motivations and barriers to the construction of green buildings on campus. International Journal of Sustainability 8(3):339-54.

Rosen, K. T. 1984. Toward a model of the office building sector. Real Estate Economics 12(3):261-69.

Simons, R. A., E. Choi, and D. M. Simons. The effect of state and city green policies on the market penetration of green commercial buildings. Journal of Sustainable Real Estate 1(1):139-66.

Theaker, I., and R. Cole. 2001. The role of local governments in fostering "green" buildings: A case study. Building Research and Information 29(5):394-408.

Tse, R. Y. C., and J. R. Webb. 2003. Models of office market dynamics. Urban Studies 40(1):71-89.

USGBC (U.S. Green Building Council). 2009. Green building for cool cities: A guide for advancing local green building politics. Report submitted by Sierra Club.

Warner, K. 2001. Managing to grow with environmental justice. Public Works Management and Policy 6(2):126-38.

Yudelson Associates. 2007. Green building incentives that work: A look at how local governments are incentivizing green development. Herndon, VA: National Association of Industrial and Office Properties. 
Appendix 1. U.S. Cities with Green Building Policies

\begin{tabular}{|c|c|c|c|c|c|}
\hline \multirow{2}{*}{ State } & \multirow{2}{*}{ City } & \multirow{2}{*}{ Regulatory policy } & \multicolumn{3}{|c|}{ Incentive-based policy } \\
\hline & & & Administrative & Financial & Technical support \\
\hline Arizona & Phoenix & 0 & & 0 & 0 \\
\hline Arizona & Tucson & 0 & & & \\
\hline California & Bakersfield & & & & \\
\hline California & Los Angeles & 0 & & & \\
\hline California & Oakland & 0 & & & \\
\hline California & Oxnard & & & & \\
\hline California & Riverside & & 0 & & \\
\hline California & Sacramento & 0 & & 0 & \\
\hline California & Salinas & & & & \\
\hline California & San Diego & & 0 & 0 & \\
\hline California & San Francisco & 0 & 0 & 0 & \\
\hline California & SanJ ose & 0 & & & \\
\hline California & San Luis Obispo & & & & \\
\hline California & Santa Ana & & & & \\
\hline California & Santa Rosa & & & & \\
\hline California & Stockton & & & & \\
\hline Colorado & Boulder & & & & \\
\hline Colorado & Colorado Springs & & & & \\
\hline Colorado & Denver & & & 0 & 0 \\
\hline Colorado & Fort Collins & 0 & & & \\
\hline Florida & Miami & & 0 & & \\
\hline Georgia & Atlanta & 0 & & & \\
\hline Hawaii & Honolulu & 0 & & & \\
\hline Illinois & Chicago & 0 & 0 & & \\
\hline Massachusetts & Boston & 0 & & & \\
\hline Massachusetts & Springfield & & & & \\
\hline Maryland & Baltimore & & & & \\
\hline Michigan & Ann Arbor & & & & \\
\hline Michigan & Detroit & & & & \\
\hline Michigan & Grand Rapids & 0 & & & \\
\hline Nebraska & Omaha & 0 & & & \\
\hline New J ersey & Camden & & & & \\
\hline
\end{tabular}




\begin{tabular}{|c|c|c|c|c|c|}
\hline New J ersey & Newark & & & & \\
\hline New Mexico & Albuquerque & 0 & & & \\
\hline New Mexico & Farmington & & & & \\
\hline New Mexico & Santa Fe & & & & \\
\hline Nevada & Las Vegas & & & & \\
\hline New York & Albany & & & & \\
\hline New York & Buffalo & & & & \\
\hline New York & New York & 0 & & & \\
\hline Ohio & Cincinnati & 0 & & & \\
\hline Oregon & Bend & & & & \\
\hline Oregon & Portland & 0 & & 0 & \\
\hline Oregon & Salem & & & & \\
\hline Pennsylvania & Allentown & & & & \\
\hline Pennsylvania & Harrisburg & & & & \\
\hline Pennsylvania & Philadelphia & & & & \\
\hline Pennsylvania & Pittsburgh & & & & \\
\hline Texas & Austin & 0 & & & \\
\hline Texas & Dallas & 0 & & & \\
\hline Texas & Houston & 0 & & & \\
\hline Texas & San Antonio & & 0 & 0 & \\
\hline Washington & Olympia & & & & \\
\hline Washington & Seattle & 0 & 0 & & 0 \\
\hline Washington & Spokane & & & & \\
\hline \multicolumn{2}{|c|}{ W ashington, D.C. } & 0 & 0 & & 0 \\
\hline W isconsin & Madison & 0 & & & \\
\hline
\end{tabular}

Note: Data on municipal policies were obtained from an Internet search by the author in October 2009. Cities that implemented new green building regulations or incentives since then are not included. 